\title{
Zbor hrvaških andragogov "Izobraževanje odraslih v Republiki Hrvaški znotraj vseživljenjskega izobraževanja" Lovran, 14,-16, februar 2002
}

Hrvaški andragogi so se po skoraj desetih letih v velikem številu zbrali v Lovranu. Zbor je organiziralo Hrvatsko andragoško društvo, danes osrednje organizacijsko žarišče na področju izobraževanja odraslih $v$ tej državi. Srečanje je povezalo mednarodno konferenco in Andragoško zimsko šolo. Za mednarodno konferenco je bilo pripravljenih 39 referatov, za andragoško šolo 17 referatov.

V ožjem organizacijskem odboru so bili Milan Matijević, Anita Klapan, Duško Petričević, zdajšnji predsednik andragoškega društva, in Ilija Lavrnja. Po odzivu udeležencev iz prakse in teoretikov izobraževanja odraslih je očitno, da izobraževanje odraslih na Hrvaškem znova dobiva svoje pomembno mesto.

Široka pahljača predstavljenih tem je opozorila, da se izobraževanje odraslih vse bolj povezuje $\mathrm{z}$ življenjem na najrazličnejših področjih. Nekateri, pretežno teoretični prispevki, so obravnavali temeljna konceptualna vprašanja, medtem ko so posamezne analize andragoške prakse razkrile tudi svojske poti vseživljenjskega izobraževanja na Hrvaškem.

Referati so bili objavljeni v zborniku (urednika Klapan in Matijević), zato avtorjem ni bilo treba ponavljati tistega, kar so že na- pisali. Domači avtorji so predstavili 32 referatov; vsi po vrsti so pritegnili pozornost prisotnih, saj so predstavitve večinoma podprli z najsodobnejšo računalniško tehnologijo.

Nastopili so znani znanstveniki s področja andragogike, brez katerih si hrvaške andragogike ne moremo zamisliti, med njimi prof. dr. Vlado Andrilović, prof. dr. Milan Matijević, prof. dr. Nikola Pastuović, prof. dr. Ilija Lavrnja, prof. dr. Anita Klapan in dr. Duško Petričević. Žal sta nekatere med njimi $\mathrm{v}$ bližnji preteklosti prosvetna politika in boj za preživetje razpršila na razna druga delovna mesta. Kljub temu se pisanju in raziskovanju na področju andragogike niso odrekli. Na konferenci so predstavili številne razprave in druga dela, objavljena $v$ zadnjih letih, nacionalno revijo Obrazovanje odraslih in glasilo Hrvaškega andragoškega društva Andragoški glasnik. Prisotni smo imeli občutek, da sta andragogika in izobraževanje odraslih po udarcih, ki sta jih doživela v času vojne in "zašolane" prosvetne politike, zdaj znova razprla krila. Izobraževanje odraslih po pravilu zrcali stanje duha $v$ družbi. Sredi represivne družbe hitro upada, v družbi, ki se demokratizira, pa se še veliko hitreje dviga. 
O doživljanju andragoške prakse so pričali številni drugi nastopajoči andragogi. Spregovorili so o usposabljanju za delo (Dinko Stary), usposabljanju za demokratične odnose (Vera Šutalo), strokovnem izpopolnjevanju učiteljev (Dragana Redžić), o posebnostih izobraževanja odraslih $v$ drugem življenjskem obdobju (Duško Petričević), o izobraževanju on-line (Mislav Balković), o postopnem izobraževanju voznikov (Benceković, Zuber, Alispahić), izobraževanju in usposabljanju na policijski akademiji (Silvio Bratković), virtualnem izobraževanju $v$ Splitu (Ivica Kartelo) pa o temeljnem izobraževanju odraslih (Sić, Nikić), izobraževanju delavcev za nevarna dela (Telebec), izobraževanju managerjev in direktorjev (Sveto Marušić) ter o internetnem in multimedijskem izobraževanju (Matijević).

Za primerjavo so prisotni prisluhnili gostom iz tujine in se seznanili z rešitvami, ki so jih za izobraževanje odraslih znotraj vseživljenjskega izobraževanja našle druge države. Johan Fassl je predstavil zdajšnji sistem izobraževanja odraslih v Avstriji, Wilhelm Köhler je kot študij primera razčlenil izobraževanje $v$ nemškem elektrogospodarstvu. Iz Slovenije je bilo več referentov: Jug, Findeisen, Ličen, Mirčeva, Radovan, Bezenšek in Krajnc. Dotaknili so se najbolj perečih problemov prakse in teorije: učne navade in vseživljenjsko izobraževanje, usposabljanje starejših zaposlenih za delo, krepitev njihove zaposljivosti in družbenega položaja, družina kot učno okolje za socializacijo odraslih, udeležba Slovencev v izobraževanju odraslih, empirična analiza motivacije odraslih za izobraževanje in vprašanja, kdo se sploh lahko vseživljenjsko izobražuje.

Prispevki so bili raznoliki, dosegli so visoko strokovno raven, kar je dalo pečat konferenci. Očitno je bilo, da so se strokovnjaki zbrali v močni želji, da izmenjajo in pridobijo nova

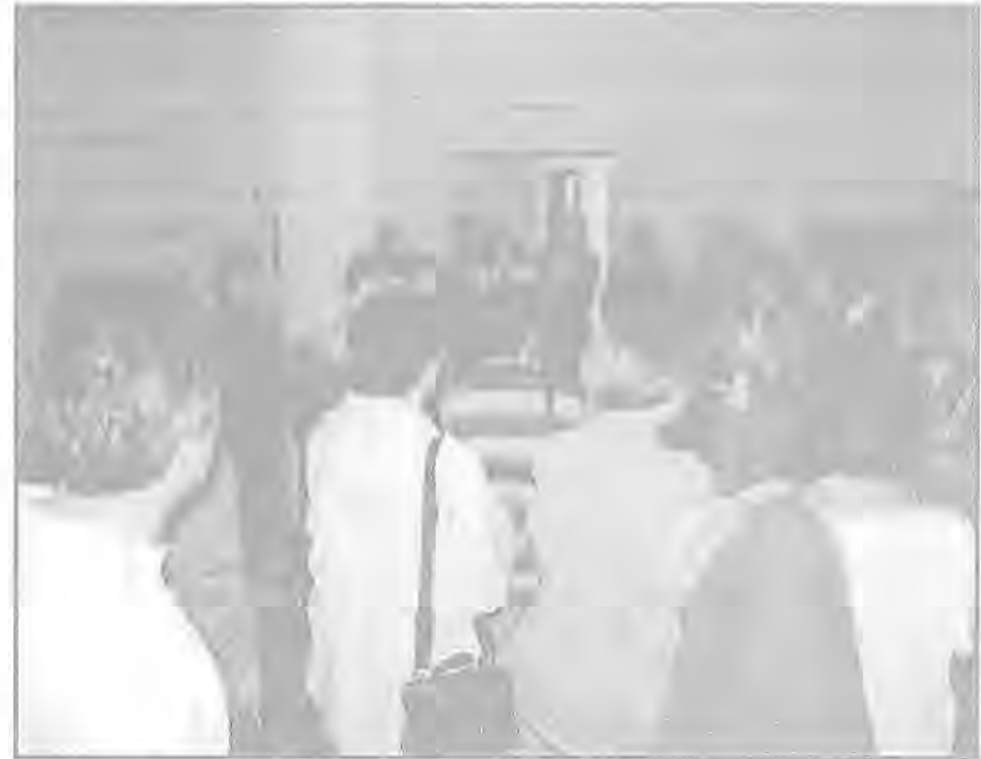

strokovna znanja. Konferenca se je zavlekla v večerne ure, udeleženci $\mathrm{v}$ dvorani pa so vztrajali. Utrujenost je očitno premagalo živo zanimanje za stroko pa tudi prizadevanje, da bi na Hrvaškem poživili andragoško prakso in se primerno odzvali na številne nove potrebe ljudi po znanju. Spoznali so, da je podpora ljudem podpora celotni družbi.

$\mathrm{V}$ andragoški teoriji in praksi ima Hrvaška dolgo tradicijo. Hrvaško andragoško društvo zdaj ne more opraviti vseh potrebnih funkcij organizacije, razvojnega dela, koordinacije in raziskovanja. Šele primerne strukture na državni ravni, kot so zavod za andragogiko, oddelek za izobraževanje odraslih pri ministrstvu za šolstvo, inštitut za andragogiko in razvojne službe za nastajanje novih mrež programov, bi omogočile, da izobraževanje odraslih dobi vloge, ki jih mora prevzeti $v$ informacijski družbi. Brez naštetih državnih organov strokovnjaki ne morejo sprožiti nikakršne široko zastavljene andragoške dejavnosti, kot je, denimo, odpravljanje funkcionalne nepismenosti in s tem nezaposljivosti nizko izobraženega dela prebivalstva.

Potrebe po izobraževanju prehitevajo ljudi, 
zato naj bo izobraževanje odraslih racionalno in načrtovano, programi dobro začrtani ali izbrani, andragoški proces pa naj bo dovolj učinkovit. Veliko dela bo še treba opraviti.

Pričakujemo, da se nam bodo hrvaški kolegi pridružili tudi na konferencah $v$ Sloveniji. Izmenjava izkušenj in spoznanj bo preprečila ponavljanje nepotrebnih napak. S tem bomo svoj strokovni prostor bistveno razširili. Kakovost strokovnih znanj je še posebej v majhnih državah odvisna od mednarodnega sodelovanja.

Prof, dr. Ana Krajnc 